Schäfera pozytywne wzmianki o wyznawcach Jahwe, które bezspornie przeważają w jego dziele $O$ Egipcie, mają niewielką wartość, albo że zdał się on całkowicie na wykreowany przez siebie szablon, który pozwala za pomocą pewnego motywu na ustalenie, kto jest, a kto nie jest antysemitą. Niewątpliwie takie „ułatwienia” prowadzą do sztucznych uproszczeń. Nie oznacza to wszakże, iż należy odrzucić w całości model proponowany przez niemieckiego uczonego. Pozwala on bowiem na uchwycenie istoty wrogości wobec Żydów, lub ostrożniej: stanowi jeden z przyczynków do zrozumienia tego niepokojącego zjawiska, jakim jest wrogość w stosunku do nich. Piszący te słowa opowiada się za ostrożniejszym stosowaniem jednolitych matryc do wielokształtnej sfery ludzkiej myśli, mającej przecież indywidualne rysy.

Pewnym mankamentem tej książki jest to, że nie traktuje ona prawie wcale o wydarzeniach, w których Żydzi nie byli wcale ofiarami. Schäfer uwzględnił w swej książce wypadki z Elefantyny, z Aleksandrii w 38 roku, prześladowania za Antiocha Epifanesa oraz wygnania z Rzymu. Nawet pobieżna znajomość dziejów narodu żydowskiego pozwala dostrzec, że wszędzie tam byli oni ofiarami Egipcjan, Greków i Rzymian. Czytelnik, skonfrontowany z taką sytuacją, jest w podobnym położeniu jak oglądający jedną stronę medalu. Autor nie wzmiankuje udziału Żydów w walkach dynastycznych Ptolemeuszy, zajęcia strony Rzymian, gdy ci najechali Egipt w 55 i w 45 r. p.n.e., rozruchów z 41 i 66 roku w Aleksandrii i wreszcie wielkiego powstania w diasporze z lat 115(6)117. Wszędzie tam Żydzi byli nie tylko ofiarami, ale odgrywali rolę aktywnych uczestników, niekiedy nawet inicjatorów tych starć. Omawiana książka nie poddaje się jednoznacznej ocenie. W swej pierwszej części prezentuje dosyć dokładną i wyważoną analizę poszczególnych źródeł, a pewne uogólnienia, np. dotyczące stosunku Rzymian do Żydów, wydają się dosyć ciekawe i nowatorskie. Jednak ogólna koncepcja dotycząca istoty antysemityzmu, choć oryginalna i nie pozbawiona wartości, powinna być stosowana nieco ostrożniej, niż to zdaje się czynić autor.

Wojciech Bejda - Lublin

\title{
Stanisław KALINKOWSKI, Jerzy Andrzej WOJTCZAK-SZYSZKOWSKI, Iure et legibus. Język taciński dla studentów prawa, Warszawa 2000, Wyższa Szkoła Handlu i Prawa im. R. Lazarskiego, ss. 232.
}

Wyrażam głęboką radość, że na rynku księgarskim ukazał się nowy podręcznik do języka łacińskiego dla studentów prawa. Studenci do tej pory mieli tylko jeden podręcznik Jana Rezlera, Język taciński dla prawników (wyd. 1, Warszawa 1970, PWN, ss. 284), który już jest nieco przestarzały i nie dostosowany do współczesnych wymogów nauczania. 
Należy ze smutkiem stwierdzić, że stan nauczania i znajomości języka łacińskiego w naszym społeczeństwie jest katastroficzny. Wystarczy włączyć telewizor czy wziąć do ręki gazetę, gdzie jest mnóstwo błędów w pisowni, w wymowie i w akcencie, nie mówiąc już o podstawowej znajomości literatury i kultury antycznej. W tych tak trudnych dla języka łacińskiego czasach ukazuje się podręcznik wspaniały, na miarę dzisiejszej epoki.

Już sami autorzy podręcznika to wybitne postacie. Pan Doktor Stanisław Kalinkowski, filolog klasyczny, świetny erudyta, ma za sobą ponad 35 lat pracy dydaktycznej na Akademii Teologii Katolickiej, obecnie na Uniwersytecie Kardynała St. Wyszyńskiego. Pan Profesor Jerzy Andrzej Wojtczak-Szyszkowski, również wybitny uczony, ma także za sobą ponad 35 lat pracy dydaktycznej i naukowej na Uniwersytecie Warszawskim. Należy dodać, że jest to w ciągu dwóch lat już drugi podręcznik Pana Profesora. Poprzedni ukazał się dwa lata temu (Jerzy Andrzej Wojtczak, Fides et Litterae. Język taciński dla uczniów szkót katolickich, studentów i alumnów, Warszawa 1998, Oficyna Wydawnicza „Adam”, ss. 400 (vide rec. „Języki Obce w Szkole” 44:2000, ss. 124-126; VoxP 17:1997, ss. 500-503). Ponadto Pan Profesor Jerzy Wojtczak jest jednym z nielicznych filologów w Polsce, który stante pede thumaczy teksty polskie na język łaciński. Jest to bardzo rzadka umiejętność w dzisiejszych zmaterializowanych czasach.

Autorzy we wstępie (s. 9-10) podkreślają, że podręcznik odpowiada współczesnym wymogom nauczania łaciny na Wydziałach Prawa. Podają całość gramatyki łacińskiej w bardzo czytelnej formie. Nauczyciel języka łacińskiego ma tutaj pełną swobodę. On sam, zdaniem Autorów, będzie decydował, jakie partie materiału gramatycznego należy przerobić, a jakie podać informacyjnie. W wiadomościach wstępnych (s. 11-15) mamy omówione bardzo jasno, poparte przykładami, następujące zagadnienia: a)Alfabet, b) Wymowa, c) Iloczas, Akcentowanie, d) Części mowy. Deklinacja. Koniugacja.

Podręcznik jest podzielony na 24 jednostki lekcyjne (ss. 16-161). Każda lekcja zawiera następujące działy: a) jasne, poparte przykładami i tablicami gramatycznymi, objaśnienia form gramatycznych lub konstrukcji składniowych, b) tekst, c) zwroty i przysłowia łacińskie w większości prawnicze. W lekcjach I-III pod tekstem podany jest słowniczek łacińsko-polski. Teksty przygotowane przez Pana Profesora są oryginalne. Układ gramatyczny podręcznika jest także oryginalny. Posłuchajmy fragmentu tekstu z lekcji XII (ss. 77-87): „Antiquis Romanis quattuor iura publica et duo privata erant. In iuribus publicis numerabantur haec: ius suffragii, ius honorum, ius provocationis, ius sacrorum. Ad iura privata ius conubii et ius commercii pertinebat. Servi omni iure carebant, nam modo laboris instrumenta habebantur". (s. 86).

W lekcji XIII (ss. 88-98) Autorzy w sposób bardzo klarowny wyjaśniają konstrukcje accusativus cum infinitivo i nominativus cum infinitivo. Oto przykłady zdań (s. 89): „Magister dicit mundum pulchrum esse. Verum est nemi- 
nem in hac terra esse felicem. Constat hunc mundum praeclarum esse". Następnie podany mamy przykład zdania: "Mundum pulchrum esse dicunt" i wyjaśnienie, że Verbum regens bywa tłumaczone nieosobowo - „Mówią, że świat jest piękny", dalej to samo zdanie podane jest w konstrukcji n.c.i., „Mundus pulcher esse dicitur” - Mówi się, że świat jest piękny”. W tej samej lekcji znajdujemy dobre przykłady $\mathrm{z}$ zastosowaniem verba deponentia: „Adoptio naturam imitatur. Dormiunt aliquando leges, numquam moriuntur”. Gerundium w lekcji XXIII (ss. 148-154) znalazło swój wyraz w pięknych między innymi wyrażeniach: „Est tempus nascendi et tempus moriendi, tempus flendi et tempus ridendi, tempus tacendi et tempus loquendi”.

W każdej lekcji spotykamy mnóstwo zwrotów, przysłów i sentencji łacińskich głównie z zakresu prawa i ustawodawstwa rzymskiego. Na stronach 162166 Autorzy wprowadzają nas w arkana kalendarza rzymskiego. Podają łacińskie nazwy miesięcy, dni tygodnia oraz uczą, jak pisać daty w języku łacińskim. Na stronach 167-229 znajdują się następujące działy: a). najczęściej spotykane zwroty i skróty lacińskie (ss. 167-172), np. de domo, de iure, per procura, primo voto; b). indeks przysłów, sentencji i powiedzeń łacińskich (ss. 173-179), np. „Imperare sibi maximum est imperium”; c). indeks sentencji prawniczych (ss. 180-190), np. „Confessio est regina probationum”. „Culpa caret, qui scit, sed prohibere non potest”. „In legibus fundamentum rei publicae”. „Ratio est anima legis”. „Testamentum est iusta sententia de eo, quod quis post mortem suam fieri velit”; d) słownik łacińsko-polski (191-229).

Szata graficzna podręcznika jest bardzo piękna, druk jasny, przejrzysty. W następnym wydaniu może warto podać przy niektórych czasownikach w słowniczku przypadek, którym rządzą np. studeo, studere (dat.) lub careo, carere (abl.). Z podręcznika tego będą korzystali nie tylko studenci prawa, ale także studenci innych kierunków humanistycznych. Może on być także bardzo przydatny w zreformowanym trzyletnim liceum ogólnokształcącym o profilu akademickim. W imieniu ogromnej jeszcze w naszych czasach liczby miłośników języka starożytnych Rzymian i kultury antycznej oraz własnym niech mi wolno będzie przekazać Wielce Szanownym Autorom podręcznika wyrazy głębokiego szacunku i uznania u progu Nowego Stulecia i Tysiąclecia imo ex corde.

Władysław Pokrywka - Starachowice

\section{Ks. Mariusz SZRAM, Orygenes o kaptaństwie. Antologia tekstów, Hosia- num, Olsztyn 1998, ss. 84.}

W wydawnictwach teologicznych ostatnich lat temat kapłaństwa pojawia się coraz częściej. Świadczą o tym dosyć liczne nowe publikacje i wznowienia 